\title{
Sociocultural Contexts of Reading Development in Young English Language Learners
}

\author{
Hsin-Hui Lin \\ Department of Teacher Leadership and New Literacies, \\ University of Houston-Victoria, United States \\ 3007 N Ben Wilson St. \\ Victoria, TX 77901, USA
}

Liping Wei

Department of Teacher Leadership and New Literacies, University of Houston-Victoria, United States

Mei-Chih Wang

Department of Urban Education, University of Houston-Downtown, United States

Received: August 25, 2018 Accepted: Oct. 29, 2018 Published: November 1, 2018

doi:10.5296/jse.v8i4.13790 URL: https://doi.org/10.5296/jse.v8i4.13790

\begin{abstract}
This study explored reading development in young English language learners (ELL) during the kindergarten year. Data used in this study came from the Early Childhood Longitudinal Study, Kindergarten Class of 2010-2011 (ECLS-K: 2011). A total sample of 15,042 students who attended kindergarten the first time was included. The independent variables were the indicators of the home language, family income level, and gender. The two dependent variables were students' reading item response theory (IRT) scale scores in the fall and spring semester of the kindergarten year. Two full three-way analysis of variance (ANOVA) models were used for the statistical analyses. The results found there is a gender difference in children's reading performance, with female students doing slightly better than male. The family income levels also show differences in children's reading performance. The higher the family income was, the better students showed in their mean reading scores. English Only Learners (EOL) had the highest mean scores, followed by the group of multilingual learners
\end{abstract}


(ML), English language learners (ELL) group had the lowest scores for both semesters. Among the 18 subgroups, the highest group was ELL-high-income-family-females in the fall semester and ML-middle-income-family-males in the spring semester. The lowest group was ELL-low-income-males for both semesters.

Keywords: Academic Performance, Child Development, English Language Learners (ELL), English Only Learners (EOL), Kindergarten, Literacy, Multilingual Learners (ML), Reading, Second Language. 


\section{Introduction}

A child's language development starts at birth and continues to grow through 12 years of age, but the acquisition of new vocabularies would continue throughout a lifetime (de Villiers \& de Villiers, 1979; Krashen, 2004). A child learns what words are and how to recognize sounds and talk about them way before he can read. He also uses language to communicate about things that are not present (Harris, Aycicegi, \& Gleason, 2003). The volume of vocabulary in a young child has a significant impact on growing his reading skills. If a child develops a large vocabulary, his path to reading is easier. With a small vocabulary, he would be at risk of learning to read, when he begins elementary school (Cunningham \& Allington, 2011).

\section{Literature Review}

Three factors, gender, socioeconomic status, and home language, often make a difference in children's language and reading development.

\subsection{Gender}

Although in general intelligence, there is no gender difference. Studies have found that some differences occur in learning reading and math between the genders. Females have slightly better verbal skills than males (Galambos, Berenbaum, \& McHale, 2009), while male students tend to have better math performance outcomes than females. For example, two national report cards in 2005 and 2007 have shown that girls did better than boys in reading and writing, however, males had higher average math scores than females in fourth and eighth grades (Perie, Grigg, \& Donahue, 2005; Lee, Grigg, \& Dion, 2007). A recent study using k-8 national longitudinal data also found the similar trend that females did better than males in reading (Robinson \& Lubienski, 2011).

\subsection{Socioeconomic status}

Children from low-income families performed less well than middle-income and high-income families on most measures of academics success. These measures include standardized test scores, school grades, high school completion rates, college enrollment, and college completion rates (Reardon, 2013). There are many reasons that lead to this disparity between the children from low and middle income. Low-income families, compared to the high-income families, have less access to the resources to raise their children (Wadsworth, Evans, Grant, Carter, \& Duffy 2016). A study showed that persistent economic hardship and early poverty link to lower cognitive function in young children (Schoon, Jones, Cheng, \& Maughan, 2012).

In addition, research findings revealed that family's socioeconomic status and the type of talk that parents use with children have impact on the child's vocabulary development (Pan \& Uccelli, 2009). Studies from the NICHD Early Child Care Research Network (2005) showed that poverty and early speech input affect a child's language development. Compared to the parents from welfare programs, parents from professional families talked more with their young children. As a result, children whose parents were professionals had double the 
amount of vocabulary than those from welfare families. By the time, children go to preschool, the disparities among the socioeconomic status contexts on language inputs in the homes and the children's levels of vocabulary have been widened (Hart \&Risley1995).

\subsection{Home language}

Students who have learned and used English from early childhood are often called the English Only Learners (EOLs), while other students whose first languages are not English and speak English only as a second language are English Language Learners (ELLs). There are also students who have used more than one language at home and use these languages equally. They are multilingual learners (MLs). Acquiring a second language often is a challenge. Some people believe for young children, it is easier. However, researchers who study second language acquisition argue such a development is a very complex process and lasts a long period of time (Cummins, 2008; Krashen, 2003; McLaughlin, 1984).

Because of limited language capability, the ELL students might not be able to communicate fluently or learn effectively in English. ELL students often face two challenges of becoming fluent in English and keeping up the academic achievement with peers. Results from a recent study showed that there were differences between the EOLs and ELLs groups on children's learning outcomes in reading performance and proficiencies. During the kindergarten year, the EOL children did better than ELL children in the development of reading proficiencies such as "letter recognition", "beginning sounds", "ending sounds", and "sight words." In the first grade, the EOL children performed better on "work in context" and "literal inference." The reading gap seemed to widen between the groups as the children finished first grade (Lin, Wei, \& Wang, 2017).

The trend of the ELL students falling behind non-ELL students remains steady. The National Assessment of Educational Progress (NAEP) analyzed the students' records from 2002 to 2017andfound that ELL students had lower reading scores than non-ELL students. In 2017, the achievement gap between non-ELL and ELL students was 37 points at $4^{\text {th }}$-grade and 43 points at the $8^{\text {th }}$-grade level (McFarland et al., 2018).NAEP used three levels to categorize students' reading skills: (1) basic level indicates partial mastery of fundamental skills, (2) proficient level indicates demonstrated competency over challenging subject matter, and (3) advanced level indicates superior performance beyond proficient. The NAEP 2005 report indicated that in the $4^{\text {th }}$ grade, nearly $73 \%$ of ELL students scored below basic requirements in reading. This percentage is much higher than their white counterparts who had $47 \%$ of the students were behind in reading (Fry, 2007).

The $4^{\text {th }}$ grade is the earliest point at which the National Report Card tracks students' academic performance. Additionally, under the United States federal "No Child Left Behind Act," the U.S. Department of Education requires each state set a standard for accountability and determine the methods and procedures for measuring students' adequate yearly progress (AYP). Reading and math are the two main content areas. The earliest grade level on the state test is the third grade. 
Understanding how young children develop reading abilities, researchers should take a more comprehensive approach by exploring the effects of gender, family income levels and home languages on young children's reading development. Furthermore, the reading development in kindergarten has a great impact on students' reading achievement. When children fell behind in early grades, such as kindergarten, students became further and further behind throughout grade school (Grossen, 1997). Thus, using students' third-grade reading AYP results to monitor students' reading development is not effective but also puts them at a greater risk for academic failures. Children's reading development starts in kindergarten or even earlier. It is important to track in the earliest stage of how ELLs develop English language skills.

\section{Purpose of the Study}

It was not clear how much progress ELL students made in reading development in the early elementary school years. In order to learn more about the impacts of background factors on ELL children, it is important to investigate reading development throughout kindergarten. Two main issues investigated are:

(1) How do students overall reading proficiencies develop during the kindergarten year? (2) In light of the contextual factors of gender and family income level, what are the differences in reading development among English Language Learners (ELLs), English Only Learners (EOLs), and Multilingual Learners (MLs) children in kindergarten?

\section{Research Method}

\subsection{Data file and samples}

Data used in this study came from the Early Childhood Longitudinal Study, Kindergarten Class of 2010-2011 (ECLS-K: 2011). The analyses were based on K-first grade data file. The ECLS-K is sponsored by the U.S. Department of Education, and the National Center for Education Statistics (NCES). The ECLS-K study selected a nationally representative sample of kindergartners in the fall of 2010 and has followed through the 2015-2016 school year when most of these children were at the end of the fifth grade (Tourangeauet al., 2015). In the year 2010, more than 18,000 students started kindergarten. To better define the scope of this study, only those students who attended kindergarten the first time, but no retainers were included. This study included a total sample of 15,042 students.

\subsection{Weights}

The ECLS-K selected a nationally representative sample of children attending kindergarten in 2010-2011 through a multistage probability sample design. In this study, the weight of W3CF3P_30 was applied to the analyses. Based on the recommendation made by the National Center for Education Statistics (NCES), using appropriate weight analyses, the results are applicable to the norm (Tourangeauet al., 2015) and educators can utilize to interpret children's performance in the population as well as help students improve reading learning outcomes. 


\subsection{Measures of independent variables}

The independent variables of this study were the indicators of the home language, family income level, and gender. The indicator of home language included three groups of students. Firstly, the English Language Learners (ELLs)group was composed of students who used non-English language at home. Secondly, the English Only Learners (EOLs) group was students who had English language at home, and the third group, multilingual learners (MLs) of students who cannot choose primary or used two languages equally at home. The indicator of family income level divided the students into three groups: low (below poverty threshold), middle (at or above the poverty threshold, below 200 percent of poverty threshold), and high (at or above 200 percent of poverty threshold). The gender indicator separated students into the male or female group.

\subsection{Measures of dependent variables}

This study has two dependent variables and were students' reading item response theory (IRT) scale scores in the fall and spring semester of the kindergarten year. The IRT scale scores are assessments of students' academic performance in reading and are composed of different sets of test items with varying degrees of difficulty. Item response theory used to equate the different tests to a common vertical scale. The IRT scale scores provide unique functions, which allow the researchers to make comparisons of achievements across the semesters.

\subsection{Statistical analyses}

Descriptive analyses were conducted for data quality checking and provide references for further analyses. Two full three-way analysis of variance (ANOVA) models were designed to test each of the three main effects, three two-way interaction effects, and one three-way interaction effect. The three main effects were gender, family income level, and home language. The two-way interaction terms were gender $\mathrm{X}$ family income level, gender $\mathrm{X}$ home language, and family income level $\mathrm{X}$ home language. The three-way interaction was gender $\mathrm{X}$ family income level $\mathrm{X}$ home language. With two subgroups for gender, three subgroups for family income level, and three subgroups for home language, the three-way ANOVA had totaled $18(2 \times 3 \times 3)$ breakdown groups. The ANOVA model estimated each parameter by fixing others as constants; thus, estimates of individual parameters were not under the influences of others in the module. The true effects were obtained. If conducting these analyses through t-test, F-test, or two-way ANOVA, the effects would be overestimated, because effects from the second or third factors were not removed. Thus, with three factors, a three-way ANOVA approach surpassed methods that could not examine all three factors simultaneously.

\section{Results}

The descriptive analyses showed that there were 7,630 (50.8\%) male students and 7,377(49.2\%) female students. The composite of students' races were 7,024 (49.7\%) White, 1,755 (12.4\%) African American, 3,421 (24.2\%) Hispanic, 1,048 (7.4\%) Asian, and 871 (6.2\%) Other. There were 2,728 (24\%) students from low-income families, 2,496 (21.9\%) from the middle-income families, and 6,154 (54.1\%) were from the high-income families. 
Among these students, 11,246 (82.2\%) students had a home language of English (EOL), while2,280 (16.7\%) students whose home language was not English (ELL) and 163 (1.2\%) students who used two languages equally at home (ML) (See Table 1).

Table 1. Demographic Information of the Students

\begin{tabular}{lrr}
\hline & Frequency & \multicolumn{1}{c}{$\%$} \\
\hline Gender & & \\
Male & 7630 & 50.8 \\
Female & 7377 & 49.2 \\
Race & & \\
White & 7024 & 49.7 \\
African American & 1755 & 12.4 \\
Hispanic & 3421 & 24.2 \\
Asian & 1048 & 7.4 \\
Other & 871 & 6.2 \\
Family Income & & \\
Low & 2728 & 24.0 \\
Middle & 2496 & 21.9 \\
High & 6154 & 54.1 \\
Home Language & & \\
EOL & 11246 & 82.2 \\
ML & 163 & 1.2 \\
ELL & 2280 & 16.7 \\
\hline
\end{tabular}

\subsection{Kindergarten - fall semester}

The average kindergarteners' reading IRT scale score for all the students was 37.58 with a standard deviation of 9.36 and a range from 21.51 to 90.35 . The mean score for the male students was 36.98 and females was 38.21. The average reading IRT score for students from the low-income family was 33.43 and from the middle-income family was 36.03 , and from the high-income family was 40.56. The comparisons on reading IRT scale scores among three home language groups were as follows: $\mathrm{EOL}=38.25, \mathrm{ML}=36.05$ and $\mathrm{ELL}=33.66$ (See table 2). 


\section{Macrothink}

Journal of Studies in Education

ISSN 2162-6952 2018, Vol. 8, No. 4

Table 2. Descriptive Statistics of Kindergartners Reading IRT Scores by Gender, Family Income, and Home Language

\begin{tabular}{lcc}
\hline & Fall & Spring \\
\hline All Student & 37.58 & 49.68 \\
Gender & & \\
Male & 36.98 & 48.80 \\
Famle & 38.21 & 50.60 \\
Family Income & & \\
Low & 33.43 & 44.42 \\
Middle & 36.03 & 48.52 \\
Hight & 40.56 & 53.04 \\
Home Language & & \\
EOL & 38.25 & 50.59 \\
ML & 36.05 & 48.08 \\
ELL & 33.66 & 44.49 \\
\hline
\end{tabular}

Among the 18 subgroups, four groups had the average score above 40, ELL-high-income-family-female $\quad(\mathrm{M}=42.22), \quad$ EOL-high-income-family-female $(\mathrm{M}=41.09)$, EOL-high-income-male $\quad(\mathrm{M}=40.42), \quad$ and $\quad$ ML-high-income-family-male $(\mathrm{M}=40.01)$. Three lowest groups were ELL-low-income-family-male $(\mathrm{M}=31.79)$, ELL-low-income-female ( $\mathrm{M}=32.07)$, and ML-low-income-female $(\mathrm{M}=32.31)$. (See table 3). 
Table 3. Descript Analyses of Tri-variables of Reading IRT Scores in Kindergarten Year

\begin{tabular}{|c|c|c|c|c|}
\hline $\begin{array}{l}\text { Home } \\
\text { Language }\end{array}$ & $\begin{array}{l}\text { Family } \\
\text { Income } \\
\text { Level }\end{array}$ & Gender & K-Fall & K-Spring \\
\hline \multirow[t]{6}{*}{ ELL } & \multirow[t]{2}{*}{ Low } & Male & 31.79 & 42.59 \\
\hline & & Female & 32.07 & 43.47 \\
\hline & \multirow[t]{2}{*}{ Middle } & Male & 33.96 & 43.65 \\
\hline & & Female & 33.30 & 44.22 \\
\hline & \multirow[t]{2}{*}{ High } & Male & 34.83 & 44.84 \\
\hline & & Female & 42.22 & 53.48 \\
\hline \multirow[t]{6}{*}{ EOL } & \multirow[t]{2}{*}{ Low } & Male & 33.79 & 44.29 \\
\hline & & Female & 34.62 & 46.29 \\
\hline & \multirow[t]{2}{*}{ Middle } & Male & 35.80 & 48.86 \\
\hline & & Female & 36.99 & 49.63 \\
\hline & \multirow[t]{2}{*}{ High } & Male & 40.42 & 52.65 \\
\hline & & Female & 41.09 & 54.05 \\
\hline \multirow[t]{6}{*}{ ML } & \multirow[t]{2}{*}{ Low } & Male & 34.53 & 44.37 \\
\hline & & Female & 32.31 & 42.93 \\
\hline & \multirow[t]{2}{*}{ Middle } & Male & 37.46 & 54.14 \\
\hline & & Female & 36.89 & 48.14 \\
\hline & \multirow[t]{2}{*}{ High } & Male & 40.01 & 53.13 \\
\hline & & Female & 37.27 & 51.92 \\
\hline
\end{tabular}

All the three main effects, two-way, and three-way interactions on the ANOVA test showed statistical significances at $\mathrm{p}^{* * *}<.001$ level: home language $[\mathrm{F}(2,3153586=) 11409.40, \mathrm{p}$ $<.001]$, family income, $[\mathrm{F}(2,3153586)=13483.05, \mathrm{p}<.001]$, and gender, $[\mathrm{F}(1,3153586)=$ $139.24, \mathrm{p}<.001]$.For the statistical analyses results of two-way and three-way interaction, please see table 4 . 


\section{Mll Macrothink}

Table 4. Three-way ANOVA Test the Effects of Home Language, Family Income Level, and Gender on Students' Reading Performance in the Fall of Kindergarten

\begin{tabular}{lrrrrr}
\hline Source & \multicolumn{1}{c}{ SS } & \multicolumn{1}{c}{ df } & \multicolumn{1}{c}{ MS } & \multicolumn{1}{c}{ F } & \multicolumn{1}{c}{ P } \\
\hline Language & 1775934 & 2 & 887967 & 11409.40 & 0.000 \\
Income & 2098710 & 2 & 1049355 & 13483.05 & 0.000 \\
Gender & 10837 & 1 & 10837 & 139.24 & 0.000 \\
Language X Income & 46176 & 4 & 11544 & 148.33 & 0.000 \\
Language X Gender & 208140 & 2 & 104070 & 1337.19 & 0.000 \\
Income X Gender & 66909 & 2 & 33455 & 429.85 & 0.000 \\
Language X Income & 979313 & 4 & 244828 & 3145.77 & 0.000 \\
X Gender & & & & & \\
Error & 245434882 & 3153568 & 78 & & \\
Total & 4782803145 & 3153586 & & & \\
Corrected Total & 279087371 & 3153585 & & & \\
& & & & & \\
\hline
\end{tabular}

Note $.-R^{2}=.121$ (Adjusted $\left.R^{2}=.121\right)$.

\subsection{Kindergarten - springsemester}

The average kindergarteners' reading IRT scale score for all the students was 49.68 with a standard deviation of 11.25 and a range from 22.06 to 90.35 . The mean score for the male students was 48.80 and females was 50.60. The average reading IRT score for students of the low-income family was 44.42 , the middle-income family was 48.52 , and the high-income family was 53.04. The comparisons on reading IRT scale scores among three home language groups were as follows: $\mathrm{EOL}=50.59, \mathrm{ML}=48.08$ and $\mathrm{ELL}=44.49$ (See table 2).

Among the 18 subgroups, the highest four groups were ML-middle- income-family-male $(\mathrm{M}=54.14)$, EOL-high-income-family-female ( $\mathrm{M}=54.05)$, ELL-high-income-family-female $(\mathrm{M}=53.48)$, and $\mathrm{ML}$ high-income-family-male $(\mathrm{M}=53.13)$. Four lowest groups were ELL-low-income-family-male $\quad(\mathrm{M}=42.59), \quad$ ML-low-income-family-female $\quad(\mathrm{M}=42.93)$, ELL-low-income family-female $(\mathrm{M}=43.47)$, ELL- middle-income-family-male $(\mathrm{M}=43.65)$ (See table 3).

The results of ANOVA test in the spring are similar in the fall semester. Again, all the three main effects, 2-way, and three-way interactions on the ANOVA test showed statistical significances at $\mathrm{p}^{* * *} .001$ level. The statistical significances from these main effects listed as follows: home language $[\mathrm{F}(2,3203531)=27271.04 .94, \mathrm{p}<.001]$, family income, $[\mathrm{F}(2$, $3203531=14934.85, \mathrm{p}<.001]$, and gender, $[\mathrm{F}(1,3203531)=179.74, \mathrm{p}<.001]$. For the statistical analyses results of two-way and three-way interaction, please see table 5. 
Table 5. Three-way ANOVA Test the Effects of Home Language, Family Income Level, and Gender on Students' Reading Performance in the Spring of Kindergarten

\begin{tabular}{lrrrrr}
\hline Source & \multicolumn{1}{c}{ SS } & df & \multicolumn{1}{c}{ MS } & \multicolumn{1}{c}{ F } & \multicolumn{1}{c}{ P } \\
\hline Language & 4774434 & 2 & 2387217 & 21271.04 & 0.000 \\
Income & 3352230 & 2 & 1676115 & 14934.85 & 0.000 \\
Gender & 20171 & 1 & 20171 & 179.74 & 0.000 \\
Language X Income & 642510 & 4 & 160627 & 1431.25 & 0.000 \\
Language X Gender & 429532 & 2 & 214766 & 1913.65 & 0.000 \\
Income X Gender & 163945 & 2 & 81972 & 730.41 & 0.000 \\
Language X Income X & 1100232 & 4 & 275058 & 2450.87 & 0.000 \\
Gender & & & & & \\
Error & 359525428 & 3203513 & 112 & & \\
Total & 8388384643 & 3203531 & & & \\
Corrected Total & 409764344 & 3203530 & & & \\
& & & & & \\
\end{tabular}

Note $\quad-R^{2}=.123$ (Adjusted $\left.R^{2}=.123\right)$.

\section{Discussion}

The ECLS-K kindergarten data file provides a unique opportunity to study children's reading development during kindergarten. In 2010, more than 15,000 students started kindergarten that year. Among those students, nearly $17 \%$ of them were English language learners. Overall, children showed various growth in reading development during the year of kindergarten.

There is a gender difference in children's reading performance, with female students doing slightly better than male over a 1-point difference. It seems to have confirmed the long-held belief in gender differences that girls are stronger than boys in verbal abilities, however, in the meantime, it has also shown that such differences are very small, which has been concluded by many previous studies (Halpern \& LaMay, 2000; Linn \& Hyde, 1989).

Children's performance in reading IRT scores has shown differences among the three groups: English Only Learners (EOL) had the highest mean scores, followed by the group of multilingual learners (ML) English language learner (ELL) group had the lowest scores for both semesters. The gaps between the EOL and ELL group were a 4-point difference in the fall semester and near 6-point difference in the spring semester. The ELL children's lower reading achievement has been distinctly illuminated in this study. The literature has shown that not only in reading development but also on many measures of academic achievement, ELLs fall behind English-speaking peers (Arends, 2015, p. 76). Cummins estimated that ELLs need two years to attain basic communication skills and five to seven years to develop academic language proficiency (Cummins, 2006). ELL children might be able to do well on the playground and in social situations, but need much more time to become skillful in learning academic content in English and in learning the English language to build reading competence. 
The family income levels also show differences in children's reading performance. The higher the family income was, the better students performed in mean reading scores. The performances from highest to the lowest were high, middle, and low family income groups. The discrepancies between the high and low-income students were 7-points in the fall semester and 8-points in the spring semester. This finding has corroborated with many research studies that illustrated the achievement gap between low and high-SES children (Eamon, 2002; Noguera, 2011). It provides more evidence indicating that family wealth, status, and power exert a deep influence on children's school learning, and reading development in particular. Children from different socioeconomic backgrounds vary in the amounts of language and vocabulary exposed to in the home environment, as well as the utterance lengths in different contexts. Low-SES children speak longer during informal, out-of-school conversations while high-SES children tend to speak more extensively during a formal, story-retelling situation (Cazden, 1972). In addition, teachers' differential treatment to students from different familial backgrounds explains the lower achievement of low-SES children, including poor reading proficiency. "Teachers may hold low expectations for these children and stereotype abilities because of the clothes worn or the use of language" (Arends, 2015 , p. 84). Teachers' low expectations lead to children's low self-esteem and low expectations for academic achievement, through which, a vicious cycle of expectations and behaviors on the part of both teachers and ELL students.

This study tested three two-way interactions and one three-way interaction on students' reading performance of both semesters in the kindergarten year. The three of two-way interactions are home language $\mathrm{X}$ family income, home language $\mathrm{X}$ gender, and family income $\mathrm{X}$ gender. The one three-way interaction is home language $\mathrm{X}$ family income $\mathrm{X}$ gender. All tests on these interactions were statistically significant. The results showed these factors of home language, family income and gender have intertwined effects on students' reading achievement.

\section{Future Studies \& Implications}

To help young children develop literacy skills, parents and teachers should provide them with a supportive environment. Children benefit most when actively participating and immersed in a wide range of interesting activities, such as listening, talking, writing, and reading experiences. Although gender, family income, and home language, all have impacts on students' reading development, family income showed the strongest impact on students' progress in reading development. For families above the poverty line, students regardless of home language, the reading performance remained similar, while ELL and ML students from low-income families showed less growth.

It is critical to provide a rich reading environment for ELL and ML children during the early elementary school years. Having well-trained ELL teachers to teach young children is a necessity for this country. The results of this study indicate that ELL training for teachers throughout each school district in every state is highly recommended. A qualified ELL teacher should know the English language system well; how to teach phonology, morphology, syntax, lexicon, and semantics. From specific ELL training teachers gain a deep 
understanding of second language acquisition what is involved in acquiring a second language, and how this process happens. In addition, to teach ELLs effectively, it is important to provide modifications and support such as adopting materials that are familiar to students, using ELLs' primary languages to support learning, helping ELLs build vocabulary, and providing scaffolds to link learners' prior knowledge to the new materials. ELL teachers can serve as the advocates for language-minority students, respect students' languages and cultures, and facilitate students' families and communities to be involved in ELL's education.

The fact that gender difference in reading development is the least significant factor in ELL students' reading proficiency points to the way of thinking many studies hold true, that is, no major, inherent differences have been found between boys and girls in general cognitive abilities. Furthermore, all these differences can be influenced through education. Teachers should be advised against perceiving and acting differently toward boys than girls because of gender stereotyping. Instead, effective teachers expect boys and girls to have similar cognitive and academic abilities, excel in all skills and subjects, display similar potential, and strive to be sensitive to the unique needs of all students.

It is important to keep track of students' reading achievement through disaggregated data for later comparison in longitudinal studies. Researchers can investigate related causal factors, such as having available resources, reading activities in the schools and at children's homes, which could cause the discrepancies in reading performance.

\section{References}

Arends, R. I. (2015). Learning to Teach (10 $0^{\text {th }}$ ed.). New York, NY: McGraw-Hill Education.

Cazden, C. B. (1972). Child language and education. New York, NY: Holt, Rinehart \& Winston.

Cummins, J. (2006). How long does it take for an English language learner to become proficient in a second language? In E. Hamayan\& R. Freeman (Eds.), English language learners at school: A guide for administrators (pp. 59-61). Philadelphia, PA: Caslon.

Cummins, J. (2008). BICS and CALP: Empirical and theoretical status of the distinction. In B. Street \& N. Hornberger (Eds.), Encyclopedia of language and education ( $2^{\text {nd }}$ ed.), 2, 71-83. Literacy. New York, NY: Springer. https://doi.org/10.1007/978-0-387-30424-3_36

Cunningham, P. M., \&Allington, R. L. (2011). Classrooms that work: They can all read and write ( $5^{\text {th }}$ ed.). Boston, MA: Allyn \& Bacon.

de Villiers, P.A., \& de Villiers, J.G. (1979). Early language. Cambridge, MA: Harvard University Press. https://doi.org/10.4159/harvard.9780674331495

Eamon, N, K. (2002). Effects of poverty on mathematics and reading achievement of young adolescents. Journal of Early Adolescents, 22, 49-74. https://doi.org/10.1177/0272431602022001003

Fry, R. (2007). How Far behind in Math and Reading Are English Language Learners? Report. Pew Hispanic Center. https://files.eric.ed.gov/fulltext/ED509863.pdf 
Galambos, N. L., Berenbaum, S. A., \& McHale, S. M. (2009). Gender development in adolescence. Handbook of adolescent psychology. https://doi.org/10.1002/9780470479193.adlpsy001011

Grossen, B., \& Center for the Future of Teaching and Learning, S. C. C. (1997). 30 Years of Research: What We Now Know about How Children Learn To Read.

Halpern, D. F., \&LaMay, M. L. (2000). The smarter sex: A critical review of sex differences in intelligence. Educational Psychology Review, 229. https://doi.org/10.1023/A:1009027516424

Harris, C. L., Aycicegi, A., \& Gleason, J. B. (2003). Taboo words and reprimands elicit greater autonomic reactivity in a first language than in a second language. Applied Psycholinguistics, 24(4), 561-579. https://doi.org/10.1017/S0142716403000286

Hart, B., \&Risley, T. R. (1995). Meaningful differences in the everyday experience of young American children. Baltimore, MD: Paul H. Brookes Publishing.

Krashen, S. D. (2003). Explorations in language acquisition and use. Portsmouth, NH: Heinemann.

Krashen, S. D. (2004). The power of reading: Insights from the research ( $2^{\text {nd }}$ ed.). Portsmouth, NH: Heinemann.

Lee, J., Grigg, W., \& Dion, G. (2007). The Nation's Report Card [TM]: Mathematics 2007--National Assessment of Educational Progress at Grades 4 and 8. NCES 2007-494. National Center for Education Statistics.

Lin, H. H., Wei, L., \& Wang, M. C. (2017). Reading Development during Early Elementary School Years in Young English Language Learners. Journal of Advances in Education Research, 2(4), 224-233. https://doi.org/10.22606/jaer.2017.24003

Linn, M. C., \& Hyde, J. S. (1989). Gender, mathematics, and science. Educational Researcher, 18(8), 17-27. https://doi.org/10.3102/0013189X018008017

McFarland, J., Hussar, B., Wang, X., Zhang, J., Wang, K., Rathbun, A., Barmer, A., Forrest Cataldi, E., and Bullock Mann, F. (2018). The Condition of Education 2018 (NCES 2018-144). U.S. Department of Education. Washington, DC: National Center for $\begin{array}{llll}\text { Education } & \text { Statistics. } & \text { Retrieved } & \text { [date] }\end{array}$ https://nces.ed.gov/pubsearch/pubsinfo.asp?pubid=2018144

McLaughlin, B. (1984). Child psychology. Second-language acquisition in childhood: Preschool children (2nd ed.). Hillsdale, NJ, US: Lawrence Erlbaum Associates, Inc.

NICHD Early Child Care Research Network (Ed.). (2005). Child care and child development: Results from the NICHD study of early child care and youth development. New York City, NY: Guilford Press.

Noguera, P. (2011). A broader and bolder approach uses education to break cycle of poverty. Phi Delta Kappan, 93(3), 8-13. https://doi.org/10.1177/003172171109300303 


\section{Macrothink}

Journal of Studies in Education

ISSN 2162-6952

2018, Vol. 8, No. 4

Pan, B. A., \&Uccelli, P. (2009). Semantic development. In. J. B. Gleason \& N. Rather (Eds.). The development of language $\left(7^{\text {th }}\right.$ Ed.), Boston, MA: Allyn\& Bacon.

Perie, M., Grigg, W., \& Donahue, P. (2005). The Nation's Report Card [TM]: Reading, 2005. NCES 2006-451. National Center for Education Statistics.

Reardon, S. F. (2013). The widening income achievement gap. Educational Leadership, 70(8), 10-16.

Robinson, J. P., \& Lubienski, S. T. (2011). The development of gender achievement gaps in mathematics and reading during elementary and middle school: Examining direct cognitive assessments and teacher ratings. American Educational Research Journal, 48(2), 268-302. https://doi.org/10.3102/0002831210372249

Schoon, I., Jones, E., Cheng, H., \& Maughan, B. (2012). Family hardship, family instability, and cognitive development. Journal of Epidemiology Community Health, 66(8), 716-722. https://doi.org/10.1136/jech.2010.121228

Tourangeau, K., Nord, C., Lê, T., Sorongon, A. G., Hagedorn, M. C., Daly, P., \&Najarian, M. (2015). Early Childhood Longitudinal Study, Kindergarten Class of 2010-11 (ECLS-K: 2011). User's Manual for the ECLS-K: 2011 Kindergarten Data File and Electronic Codebook, Public Version. NCES 2015-074. National Center for Education Statistics.

Wadsworth, M. E., Evans, G. W., Grant, K., Carter, J. S., \& Duffy, S. (2016). Poverty and the development of psychopathology. In D. Cicchetti (Ed.), Developmental psychopathology: Risk, resilience, and intervention, 4, 3rd ed. (pp. 136-179). Hoboken, NJ: John Wiley \& Sons Inc. https://doi.org/10.1002/9781119125556.devpsy404 